\title{
OBSERVATIONS ON DARK GREY BASAL TILL IN FINLAND
}

\author{
HEIKKI RAINIO and PERTTI LAHERMO *
}

\begin{abstract}
HEIKKI RAINIO and PERTTI LAHERMO 1976: Observations on dark grey basal till in Finland. Bull. Geol. Soc. Finland 48, 137-152.

Dark grey basal till of boulder clay type is widespread throughout Finland. It occurs directly on the ice-polished bedrock surface on the lee-side of hills and is overlain by common till or sorted sediments. Presumably in secondary position, it occurs in a few places in Central Finland in the proximal part of ice-marginal formations. The basal till is richer in clay and humus and is also more compact than common till. In Central and Eastern Finland brown layers are encountered in the lower and upper parts of the basal till. The colour seems to be derived from oxidation. The pebble orientation in the basal till is parallel to the direction of the glacial striae on the underlying bedrock surface. The humus incorporated gives ${ }^{14} \mathrm{C}$ ages exceeding 37,000 and 45,000 years. The basal till seems to date from the initial phase of the youngest Weichselian glaciation in Finland.
\end{abstract}

Heikki Rainio and Pertti Lahermo, Geological Survey of Finland. SF-02150 Espoo 15, Finland.

* Each of the authors bears equal responsibility for this study.

\section{Introduction}

Since the spring of 1974 we have been studying a certain basal till that occurs throughout Finland and is readily distinguished from common sandy till by a number of conspicuous features, the most striking being its dark grey, sometimes blueish hue. This dark basal till resembles the boulder clays rich in fines that are encountered south of the Baltic in the marginal zone of Scandinavian glaciation (cf. Fig. 10, curve 4).

Dark basal till is not an unknown phenomenon. There are reports of it in the literature
(Virkkala 1959, Kujansuu 1974, 1975) and also a few oral accounts (the above authors and some others). Moreover, we have often received information indicating its existence from contractors and excavator operators. A basal till of analogous type is also known in Sweden (G. Lundquist 1963; J. Lundquist 1958, 1973), in Norway (Låg 1948) and in the Kola peninsula (Armand et al. 1969). So far, however, none of the dark basal till occurrences has been submitted to detailed investigations, and their stratigraphic position in the history of the late Pleistocene in Fennoscandia is still open to conjecture. 


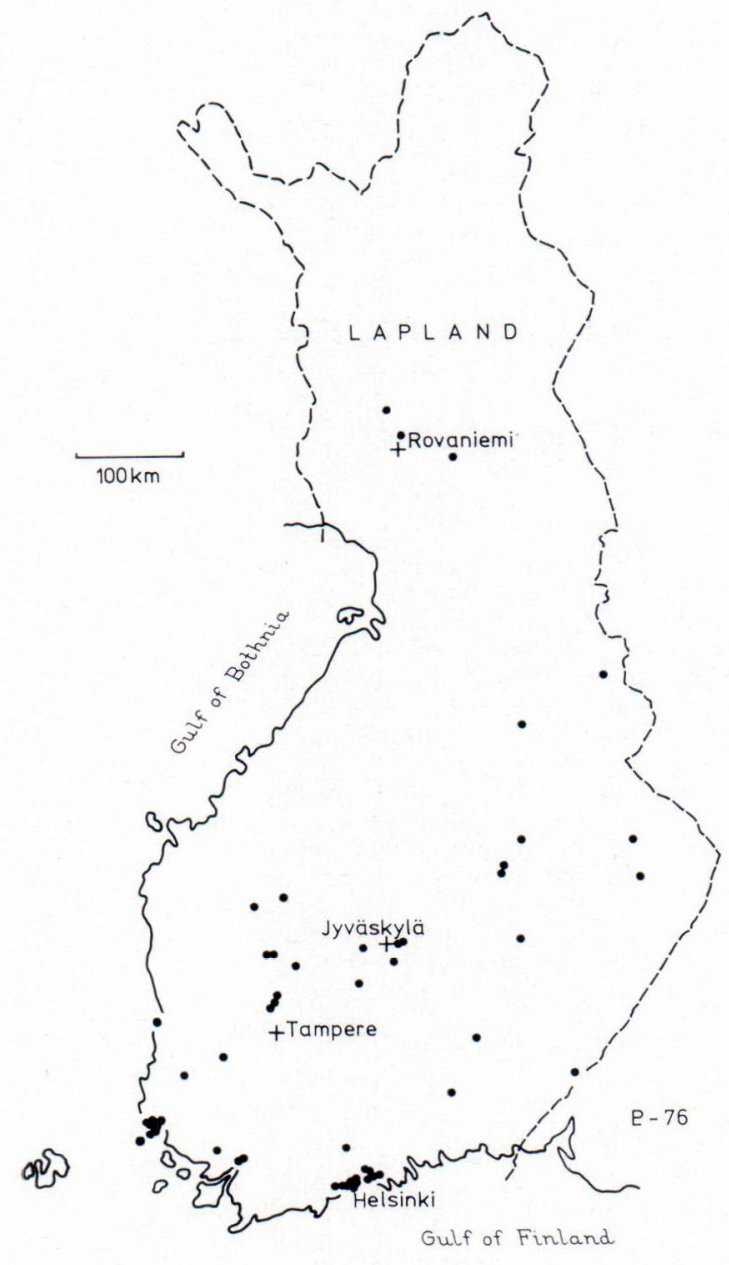

Fig. 1. Occurrences of dark grey basal till. One point may indicate several adjacent occurrences.

\section{The occurrence of dark basal till}

\section{Regional occurrence}

We have discovered dark grey basal till at almost fifty sites in Finland (Fig. 1), many of them including several occurrences within a small area. If all of these are taken into consideration, the number of occurrences approaches one hundred. This is a large number, considering the short time within which they have been discovered, and we have every reason to believe that dark basal till is fairly common throughout the country. Up to now the sections exposed by excavation have not been submitted to systematic studies. Consequently, little attention has been paid to dark basal till, particularly since it tends to occur in the lower parts of cuttings, and is soon covered with sliding earth. However, by observing its characteristic mode of occurrence and location we have succeeded in tracing numerous concealed occurrences on the basis of till fragments scattered around during excavation. Even so, many occurrences are only indicated by scattered fragments.

\section{Stratigraphic position}

In its primary position, dark grey basal till most commonly directly overlies the ice-polished bedrock on the lee side of hills (Figs. 2, 3 and 5, sketches $\mathrm{E}$ and $\mathrm{F}$ ) or in depressions of bedrock (Fig. 4). It has also been found on the stoss side of hills (Fig. 5 sections $\mathrm{A}$ and $\mathrm{C}$ and Fig. 12), where the exaration due to plastic ice has not always been so intense as on the lee side, which is characterized by broken rock. In some places the bed of basal till is visible on bedrock in the walls of cuttings as a band only a few centimetres or decimetres thick, which after a short distance disappears altogether (Fig. 6). Thus, the last exaration seems to have demolished most of the dark basal till, and it has survived only at more sheltered sites.

As a rule the dark basal till is overlain by markedly different common till, pale brown or grey in colour and rich in sand fraction. In a cutting at Peräseinäjoki (Fig. 4) and in another at Koivukylä, Vantaa, two distinct till beds overlie dark basal till. In another cutting at Koivukylä two till beds have been 

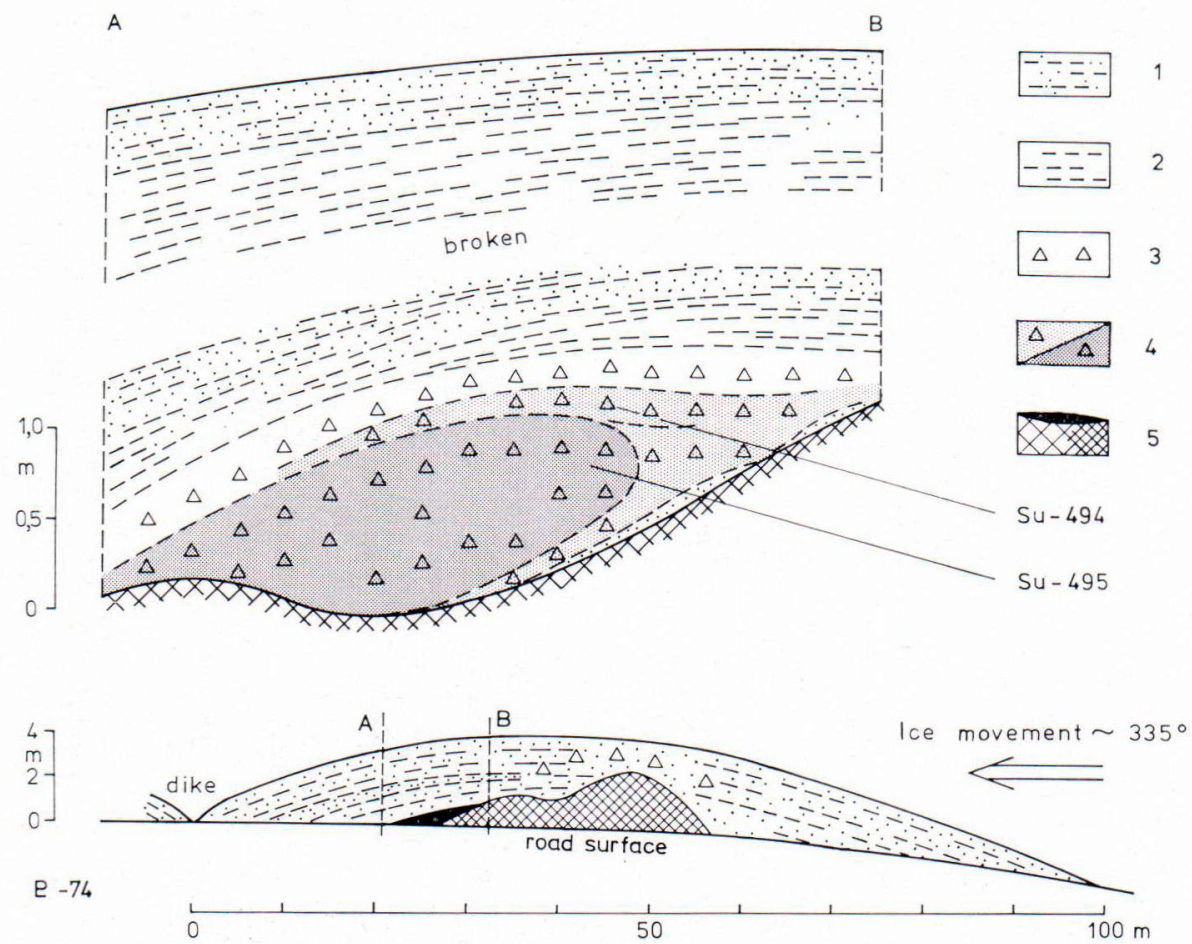

Fig. 2. Dark grey basal till on polished bedrock on the lee side of a knoll (long-section at the bottom), and detailed illustration along section $\mathrm{A}-\mathrm{B}$. The direction of the section is $\mathrm{N} 20^{\circ} \mathrm{W}$. The brown layer of the section (light hatching) can be seen in the upper part and also partly in the lower part of the bed of dark basal till (dark hatching). The ${ }^{14} \mathrm{C}$ ages ware determined from the middle dark (Su-495) and overlying brown layers (Su-494). Honkalanmäki, road cutting between Pengonpohja and Kuru. Symbols: 1. Partly stratified fine and medium sand; 2. Partly stratified silt and fine sand; 3 . Common light brown sandy till; 4. Brown and dark grey basal till from the same unit; 5. Dark and brown basal till overlying polished bedrock.

revealed in which the lower one shows signs of dark basal till as well as capture pattern. Dark basal till is often overlain by deposits of fine and medium sand that include till-like portions and littoral or slope deposits and possibly also silty or sandy lacustrine or marine sediments (cf. Figs. 2 and 3). We have not encountered any till under the dark basal till. In the rural commune of Kajaani we unearthed dark basal till underlain by a sand bed several metres thick and overlain by common till. At Herttoniemi, a suburb of Helsinki, the dark basal till is covered by delta-like glaciofluvial deposits.

In the ice-marginal formation of Central
Finland, five occurrences of dark basal till have been encountered in the proximal part of a delta or end moraine, presumably in secondary position (Figs. 7 and 8 ). In each of these occurrences, the basal till is overand underlain by glaciofluvial sand and gravel or by some till-like deposit typical of the proximal side. Beds of basal till are generally so bent that it is easy to assume they were transported by the ice sheet. An exception is the well-preserved basal till bed in the proximal part of the delta at Kerkkolankangas (Fig. 7). Here, the secondary position of the basal till is further indicated by the fact that the bed joins the till 

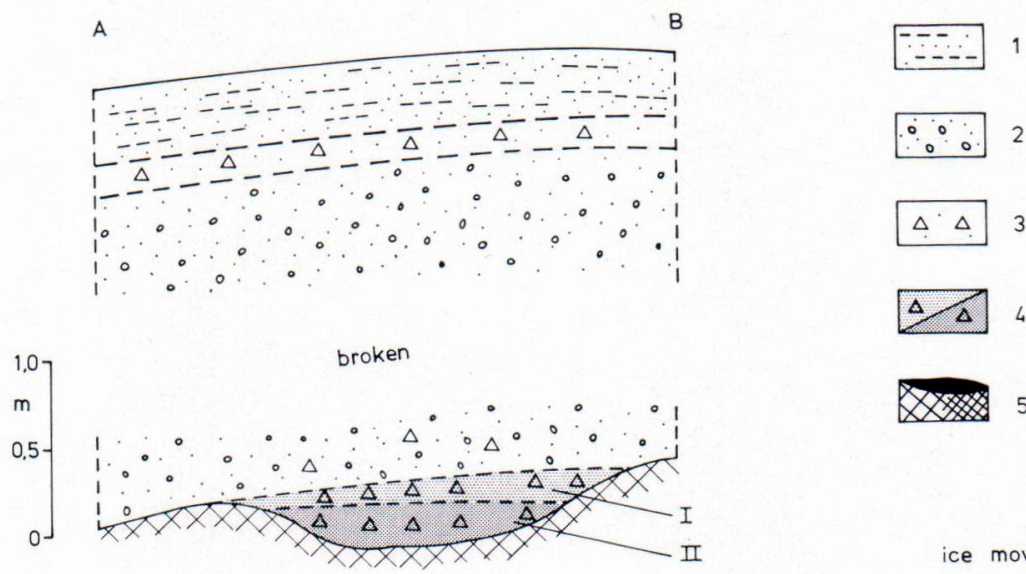

ice movement $325-330^{\circ}$

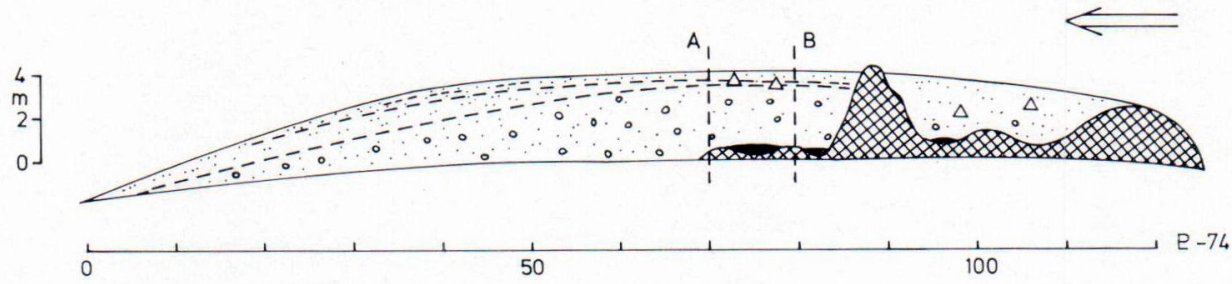

Fig. 3. Dark grey basal till on polished bedrock on the lee side of a knoll (long section at the bottom) and a detailed illustration of section $\mathrm{A}-\mathrm{B}$. The direction of the section is $\mathrm{N} 10^{\circ} \mathrm{W}$. The upper part of the basal till bed is brown. Both beds were submitted to orientation analyses (I, II, cf. Fig. 13). Väkkärämäki, road cutting between Pengonpohja and Kuru. Symbols; 2. Sand and gravel; 3. Partly sorted sandy till. Other symbols as in Fig. 2.

mantle overlying the proximal slope (Fig. 8, section D). This cover was deposited during the final oscillations of the ice sheet margin.

\section{Structure and properties of dark basal till}

\section{Thickness of bed}

The thickness of dark basal till bed usually varies from half a metre to two metres, although some thicker beds have been encountered. In foundations excavated at Sörnäinen, Helsinki, for example, there is a till bed that reaches a thickness of at least $10 \mathrm{~m}$. In Salo, a bed has been noted where basal till is visible for 4 to $5 \mathrm{~m}$, and in Peräseinäjoki a bed has been exposed for over five metres. It is often difficult to establish the total thickness of a bed owing to the lack of information concerning the location of the bedrock.

\section{Internal structure}

At several sites in Central and Eastern Finland the dark basal till is composed of two or three layers that differ from each other in colour. The top layer is greyish brown or reddish brown, the middle one dark grey or even blueish, and the bottom layer analogous to the top one. Sometimes, however, the brown bottom layer is altogether lacking. The best-developed structure of this kind has been unearthed at Kerkkolankan- 


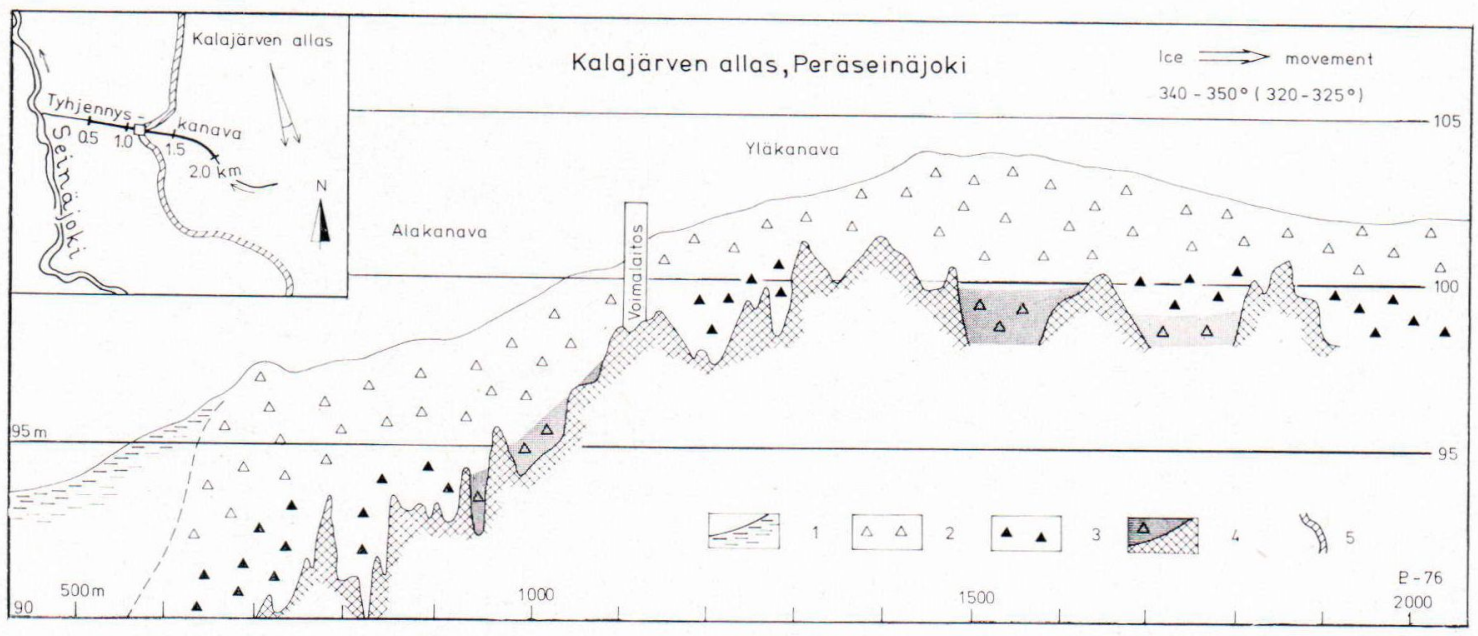

Fig. 4. Dark grey basal till in depressions of bedrock. The drainage channel (tyhjennyskanava) of the Kalajärvi reservoir flowing into the river Seinäjoki at Peräseinäjoki. The degrees in parenthesis indicate the direction of older ambiguous striations under the basal till. Symbols: 1 . Clay and siilt; 2 . Common saondy till; 3. Grey sandy till; 4. Dark grey basal till in the depressions of bedrock; 5 . Earth dam.

gas, where the three-layered structure predominates (Fig. 8 and 9 a). The brown layers encountered vary from 10 to 30 centimetres in thickness. The sequence with three layers is also visible in the Honkalanmäki occurrence (Fig. 2), and the sequence with two layers in the Väkkärämäki occurrence (Fig. 3).

The difference in colours is very pronounced and this led us to believe at first that the various layers represented basal till of three different ages, especially since some local structural differences were also in evidence. The dark grey layers tend to be massive, whereas the brown layers sometimes exhibit layered structure and bands of iron precipitates (Fig. 9 a). Glaciodynamic or glaciotectonic structures are occasionally encountered, as are some small sand lenses (Fig. 9 b). This unit of two or three layers occurs so regularly (in Central and eastern
Finland) that the brown layers can be assumed to have derived through alteration from the dark layers. This concept is corroborated by the difference in the state of iron oxidation (Tabile 2). The distinctly brown layers have not been found up to now anywhere in southern or western Finland.

\section{Density and plasticity}

The dark basal till is compact, and contractors and excavator operators have often complained that it is difficult to work with. It is similarly difficult to submit it to orientation analysis or even to take samples from it. When moist, the dark grey layer is often plastic; the brown layers are less so and the coarse-grained sandy dark grey basal tills are not plastic at all. The plasticity 


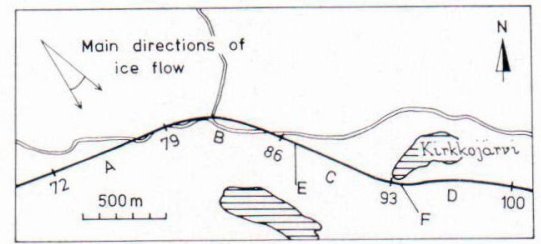

Tielinja Vehmaa-Lokalahti, Vehmaa
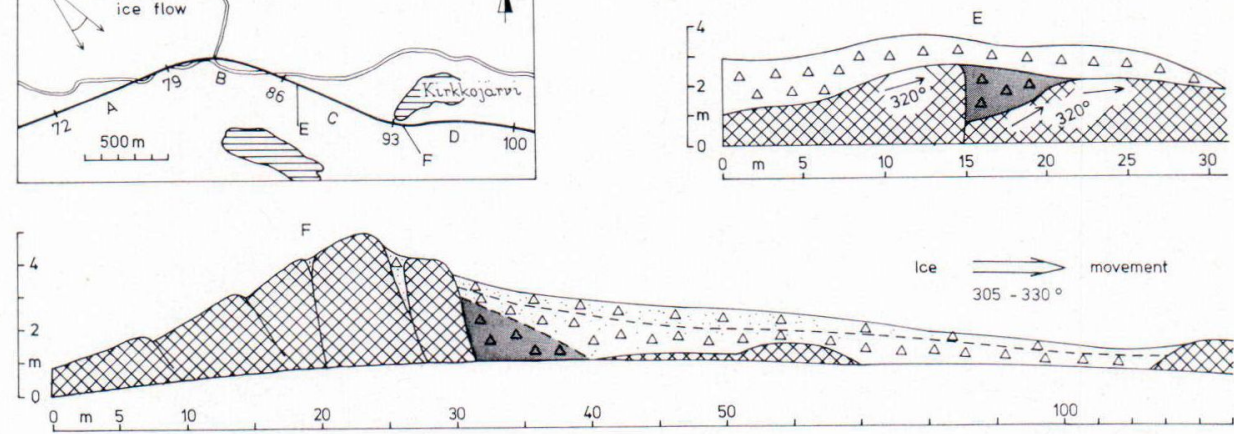

A
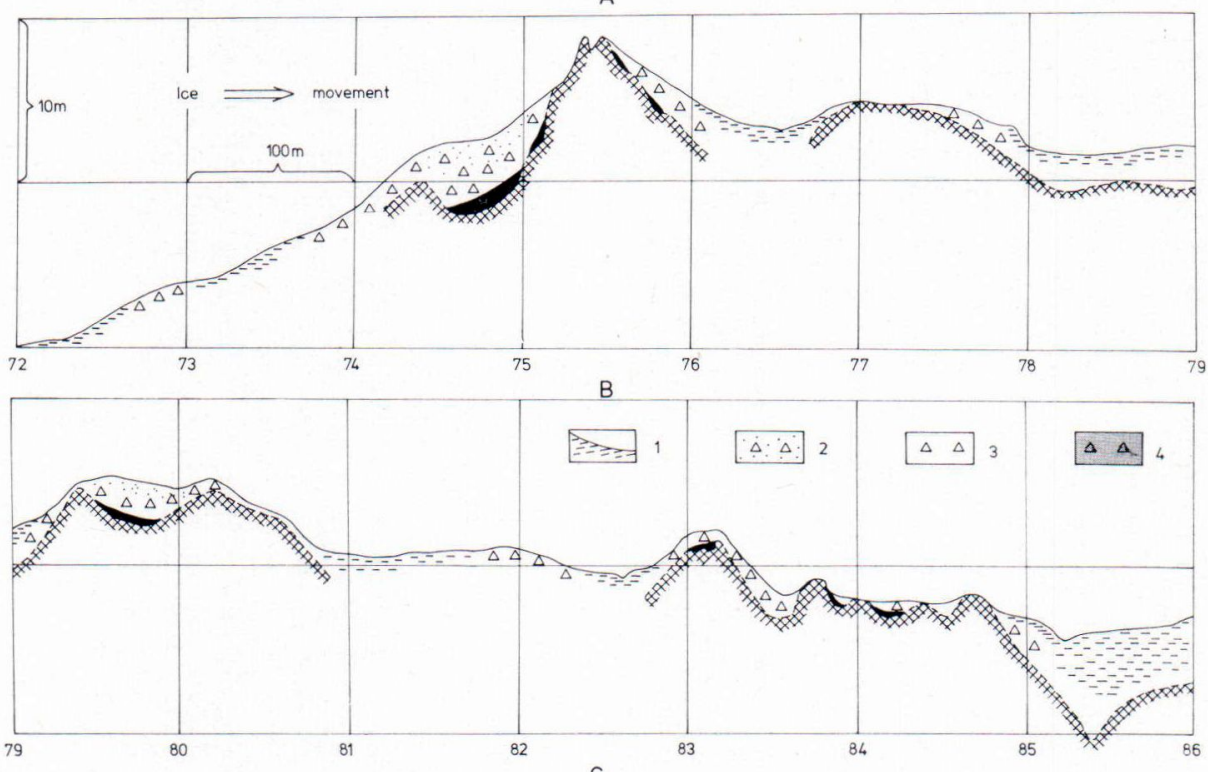

C
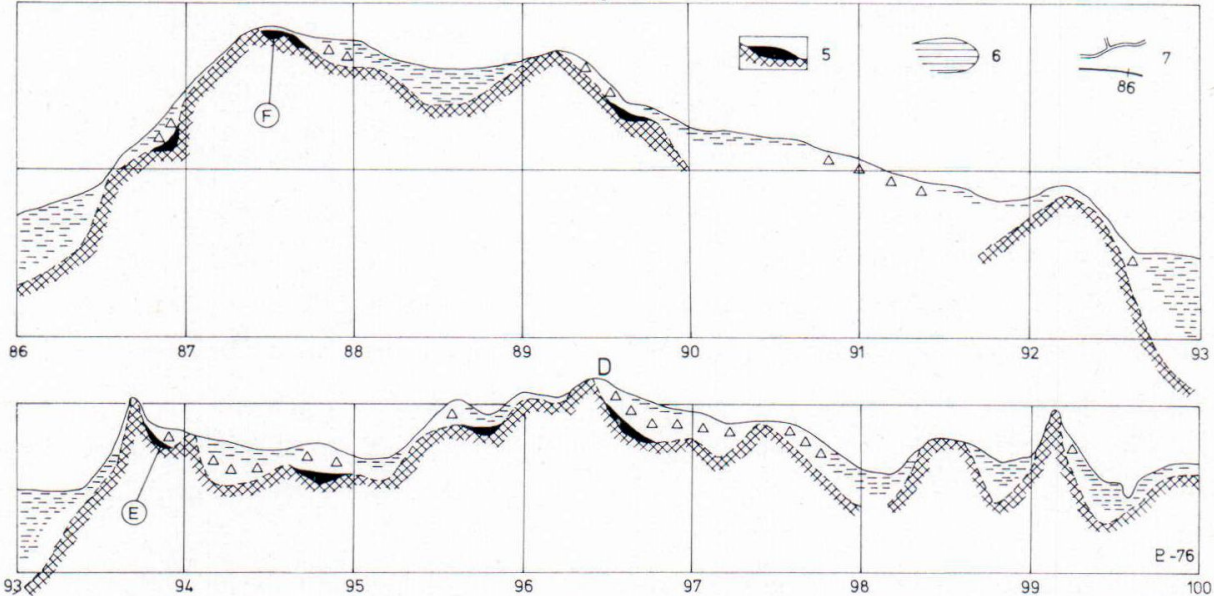


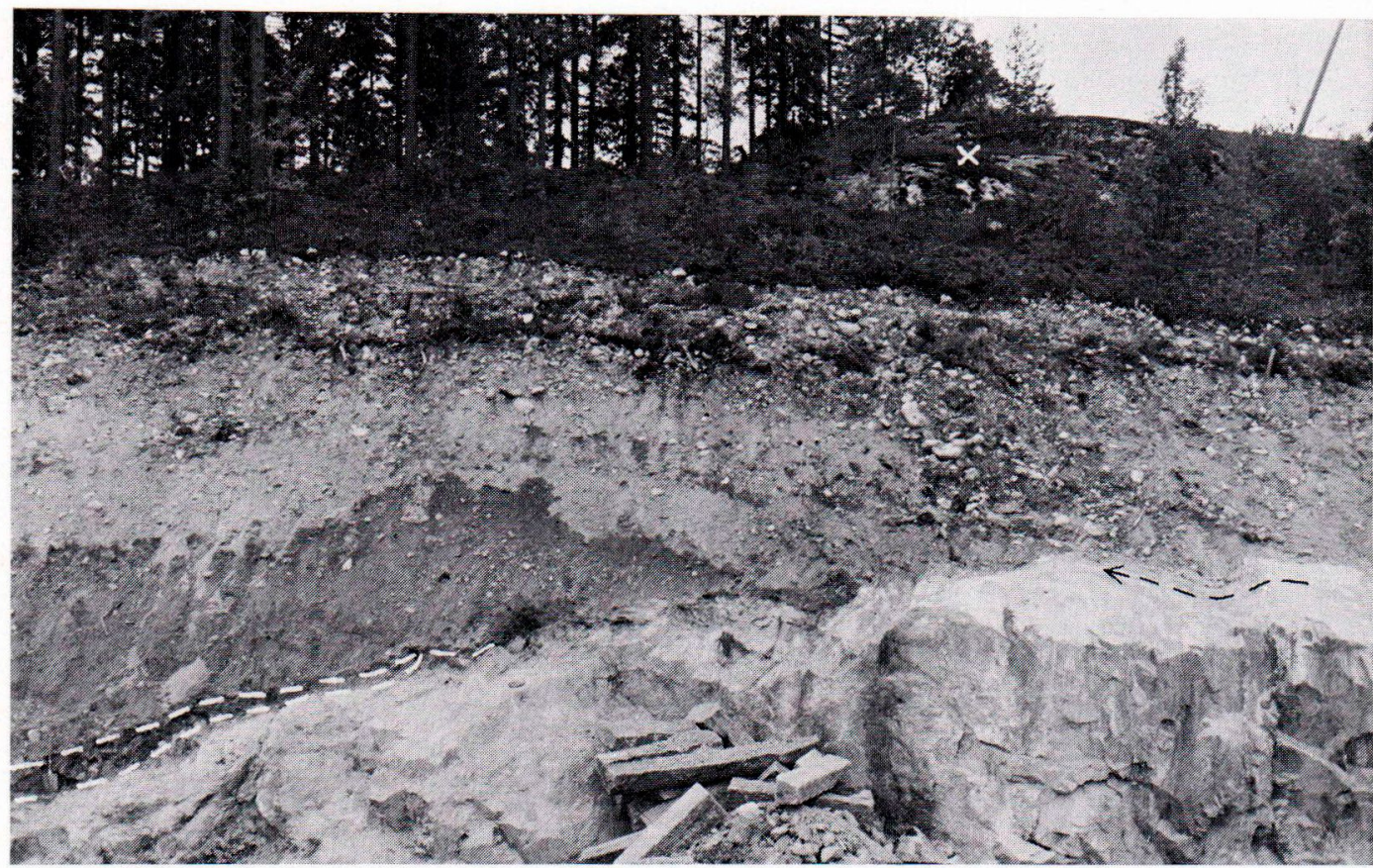

Fig. 6. Dark grey basal till at the surface of bedrock as a narrow stripe that tapers and finally vanishes. The basal till is overlain by sandy common till (grey layer), and washed till-like sand and gravel and littoral deposits (light layer). The outcropping bedrock is seen to the right in the background (x). Road cutting at Maunula, a suburb of Helsinki.

is mainly due to an abundance of clay and silt. The dark grey basal till is more plastic than are other types of till with the same grain size. The difference is conspicuous even between the layers of brown and dark grey layers in the same unit, despite the lack of variation in grain size. The plasticity may be less well developed in the brown layer because of the iron oxide coating that reduces the adhesive property of the grains.

\section{Grain-size composition and rock types}

There is a conspicuous proportion of clay in all the layers of a dark grey basal till bed, frequently exceeding the values for common till, and occasionally being as much as 20 to 22 percent (Fig. 10, curves 1), and in one sample as much as 32 per cent. In South Finland, notably in numerous occurrences of basal till around Helsinki, the percentage of clay

Fig. 5. Occurrences of dark grey basal till in road cuttings between Vehmaa and Lokalahti (map in upper left-hand corner) with four sections A, B, C and D (in the lower part of figure). Dark basal till occurs on both stoss and lee sides of knolls and hills. In detailed section $\mathrm{E}$ dark basal till occupies a fracture depression rounded and polished by the ice sheet. The striations continue at the bottom of the depression in the same direction as under the common sandy till. In detailed section $\mathrm{F}$ basal till occurs on the lee side of a steep knoll. Dark basal till is covered by common sandy till and washed till-like sand and possible littoral deposits. Symbols: 6 . Lake; 7. Old road and new road line. Other symbols as in the previous figures. 


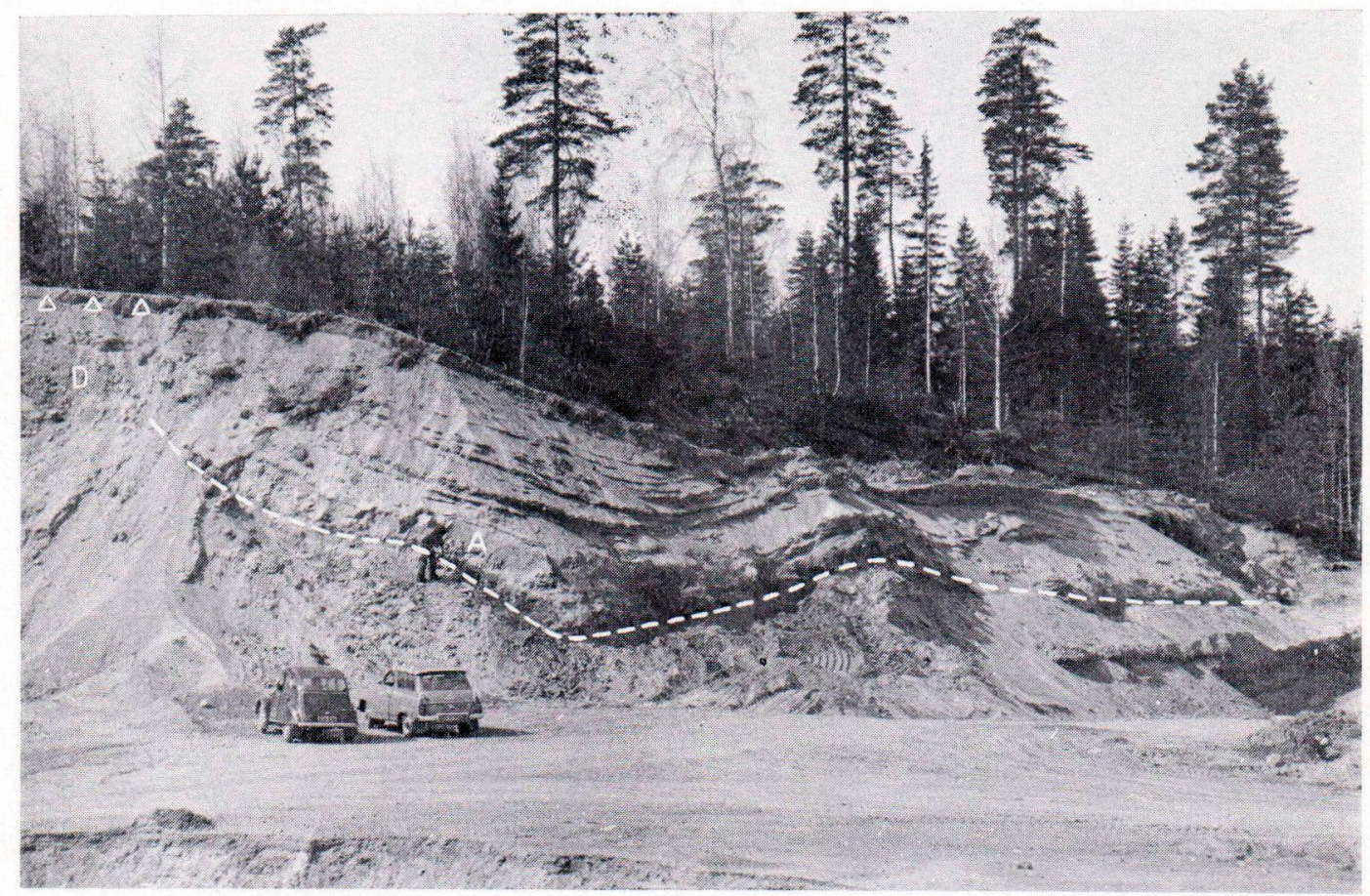

Fig. 7. A dark grey basal till bed, 40 to $80 \mathrm{~cm}$ thick, with brown layers in the proximal part of the Kerkkolankangas delta (site indicated by the dashed line), Jämsänkoski (cf. Fig. 8 and 9 a). The upper and lower glaciofluvial sand and gravel beds are compatible with the basal till bed.

is conspicuously below average, often being below 10 percent.

Common sandy till in Finland averages less than 5 percent clay (cf. Virkkala 1972). Sometimes the dark grey basal till is practically without coarse fractions. As a rule, the pebbles are small. Dark basal till with large boulders is rare.

The conspicuous dark grey colour of the basal till studied distinguishes it from common till. Although the dark grey sandy basal tills in southern Finland are paler in colour, they are still distinctly darker than common sandy tills.

The characteristic colour of dark basal till does not seem to be due to its lithological composition. Visually estimated, it is no richer in dark rocks or minerals than are common tills in the same area. Detailed study of the samples is still in progress and the effect of lithological factors on colour has yet to be established.

\section{Orientation of pebbles and relation to striations}

The dark grey basal till and the overlying common till were both submitted to orientation analysis. In some of the dark basal till beds virtually no orientation was detected, and in others the distinct orientation maxima deviated little or not at all from the orientation of the near-by striations of the last glacial movement (Figs. 12 and 13). In an occurrence at Vehmaa on the west coast, basal till overlies the polished surface, whose erosion facet and striations extend unchanged 

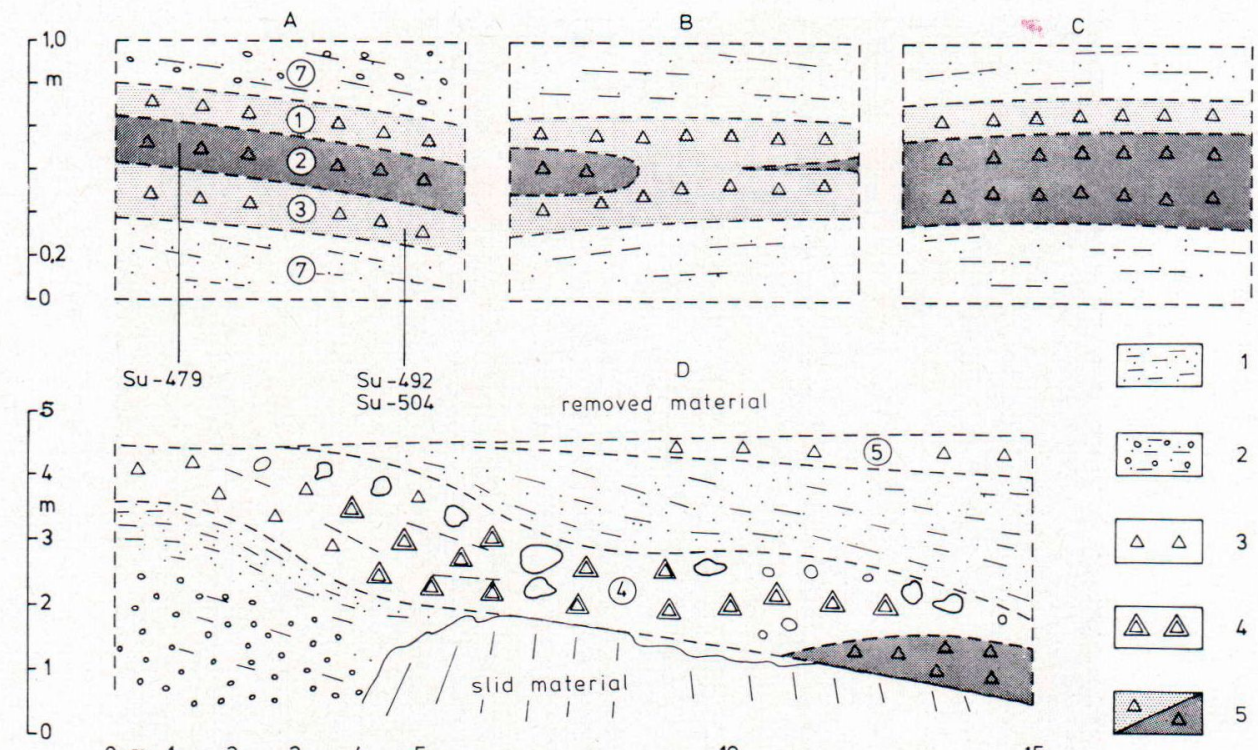

removed material

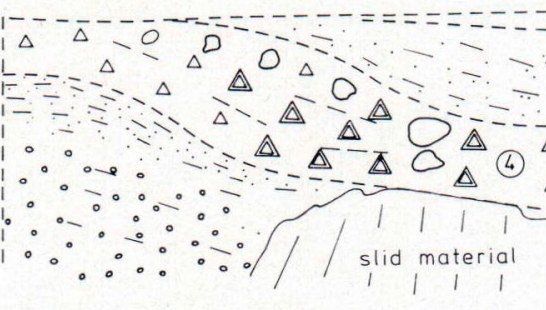

$0 \mathrm{~m} \quad 2 \quad 2 \quad 3 \quad 4 \quad 5$
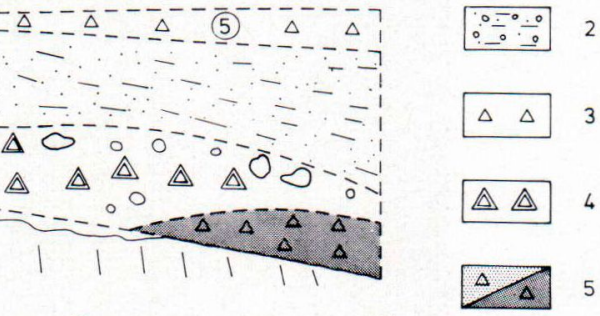

$\mathrm{e}-76$

Fig. 8. Details of the basal till bed in the proximal part of the Kerkkolankangas delta (cf. Fig. 7). In section $\mathrm{A}$ the brown layers are both above and below the dark basal till. In section B the basal till bed comes to an end or tapers to a narrow strip. In section $\mathrm{C}$ the brown basal till is only found as the upper layer. In section D (cf. Fig. 7) the dark basal till continues as light-coloured basal till with unchanged grain size (cf. Fig. 11, curves $1-3$ and 4), grading into common sandy till and presumably merging with the till mantle of the proximal slope. The ${ }^{14} \mathrm{C}$ ages were determined from the middle dark and lower brown layers (section A). The numbers in the sections refer to soil samples (Fig. 11). Symbols: 2. Stratified sand and gravel; 4. Light-coloured compact till, rich in fines. Other symbols as before.

beneath the common till and litoral deposits (Fig. 5, section E). At a few investigation sites, striations found on the polished surface of the bedrock underlying the basal till bear in a somewhat more westernly or northernly direction than do the youngest striations in the same area (Fig. 4). In one occurrence at Herttoniemi, a suburb of Helsinki there are northern or north-northeastern striations under dark basal till, which presumably represent older ice movement than that of the youngest northwestern striations. The deviation between directions of the striae ranges $35-40^{\circ}$.

At first we assumed that the brown and dark basal till beds were of different age. Consequently, in a section at Väkkärämäki orientation analyses were performed on both the dark and the overlying brown layers (Fig. 3). No distinct differences were noticed, however, in the orientation of the pebbles (Fig. 13), a finding that favours the concept of a single bed in which the brown colour is due to oxidation.

\section{Humus content}

The humus content usually varies between 0.3 and 0.9 percent (39 samples average 0.53 percent). In South Finland, in the dark basal till poor in clay, the humus content is distinctly lower. Some samples are exceptionally rich in humus, assaying up to 4.5 per cent. The figures obtained, however, may be too high, owing to possible interference from iron. Nonetheless, dark basal till is 


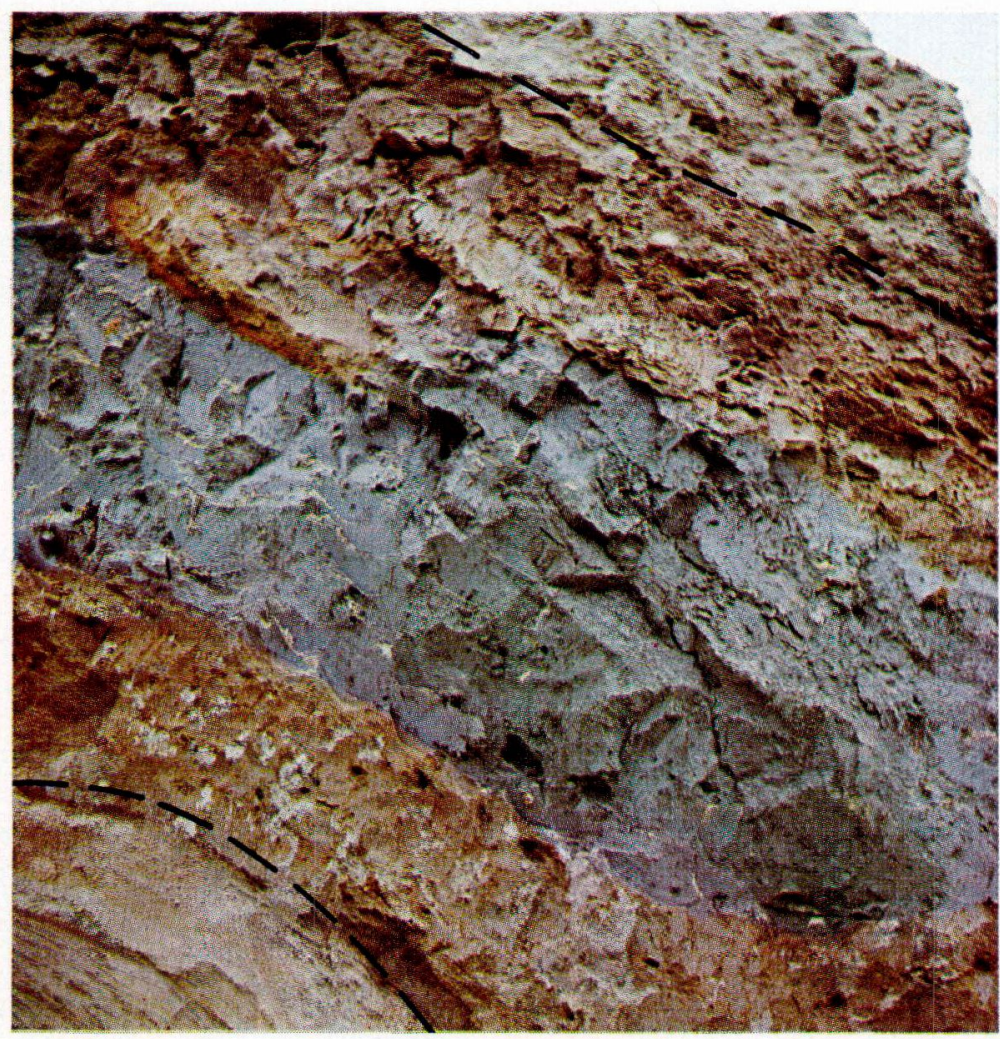

Fig. 9 a. A bed of dark basal till with upper and lower brown layers (delimited with broken lines) surrounded by stratified glaciofluvial sand (cf. Figs. 7 and 8 , section A). Some iron ferrigineous precipitates are seen at the contact between the dark grey and brown layers. The Kerkkolankangas delta, Jämsänkoski.

richer in organic matter than is common sandy till, whose humus content is generally between 0 and 0.2 percent (18 samples average 0.07 percent).

\section{Chemical composition}

Analytical data for 17 elements were obtained from each sample at the Chemistry and Geochemistry Departments of the Geological Survey.* These data are, however, too

* Samples were dried and sieved to get the $<0.06 \mathrm{~mm}$ fraction for analyzing. Analyses were made by optical emission spectrometry with an ARL tape-in-tape-out quantometer. meagre too allow any final conclusions to be drawn. Nonetheless it does seem that the brown oxidised layers are poorer in the elements analysed than are the dark grey layers (Table 1). A partial explanation for this may be the leaching effect of vadose water, which is naturally most intense in the outer portions of a bed. No significant difference was detected between the dark basal till and the common till.

Manganese determinations made in the Chemistry Department show that the abundance of manganese is too low to cause the dark colour. However, the content of ferric iron is higher in the brown layers (Table 2), which suggests that these layers are oxidised 


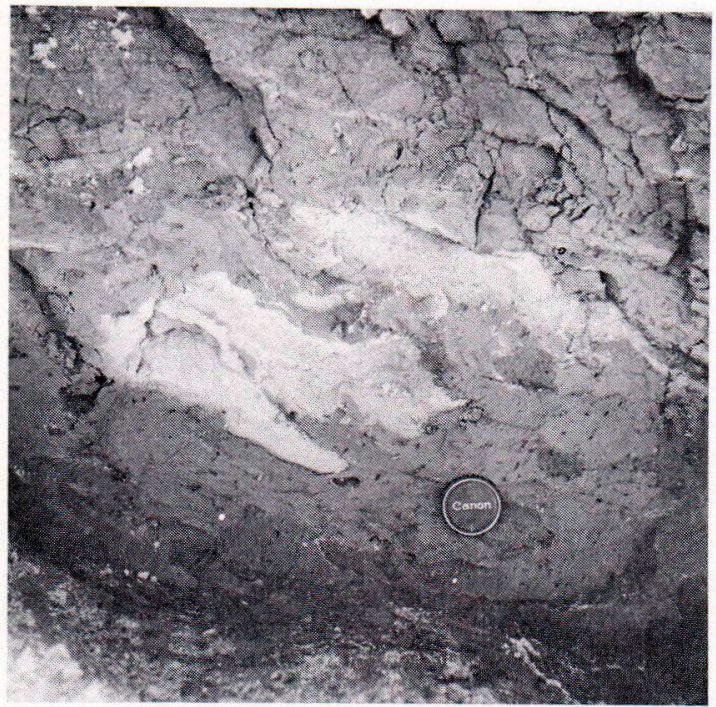

Fig. 9 b. A dark basal till bed with a brown layer in its upper part. Distorted lenses composed of fine sand are visible, especially in the upper brown part. In the dark basal till the sand is grey in colour. Iron has precipitated along the margins of the lenses. In this figure the dark colour grades gradually to a brownish hue, and not with sharp boundaries as is generally the case. Layered structure is visible in the upper brown layer. The same occurrence as in the previous figure.

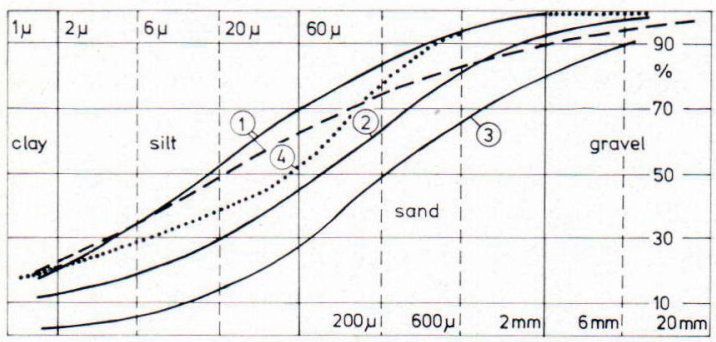

Fig. 10. Cumulative curves indicating grain size composition for basal tills and common tills. 1. Two analyses from dark basal till from the Kerkkolankangas delta (continuous line) and one from Virrat (dashed line) where the basal till rests on bedrock and is underlain by a bed of common sandy till with a thickness of 4 metres. 2. Average grain size composition of the dark basal tills (34 analyses). Some of the samples are rich in sand (especially from southern Finland), lowering the average claycontent. 3. Average composition of common till according to Virkkala (1972) (over 2,600 analyses). 4. Boulder clay from northern Poland (dotted line, 5 analyses). portions of dark layers. According to two analyses from $0.05 \mathrm{~mm}$ fraction made at the Department the dark basal till from Kerkkolankankas occurrence contained 0.14 percent Sulphur and the corresponding brown material of it only 0.08 percent. So, the colour may be subscribed to ferric iron and sulphates reduced to ferrous sulphide by the organic material contained in the basal till.

\section{Dating and microfossil assemblage}

Four samples were submitted to ${ }^{14} \mathrm{C}$ dating. They were selected when we still thought that the layers of different colour were of different age. Mr. A. Heikkinen, Phil.Lic. made three determinations from the basal till bed in the Kerkkolankangas ice-margin formation in Central Finland (Fig. 8). The dark grey middle layer was dated at more than 45,000 years $(\mathrm{Su}-479)$, and the underlying brown layer at over 37,000 years (Su492). An extra determination from the dark grey layer gave a date of over 45,000 years (Su-504). The brown layer in the Honkalanmäki basal till bed and the underlying dark grey layer (Fig. 2) were assigned dates of more than 45,000 years (Su-494 and Su-495).

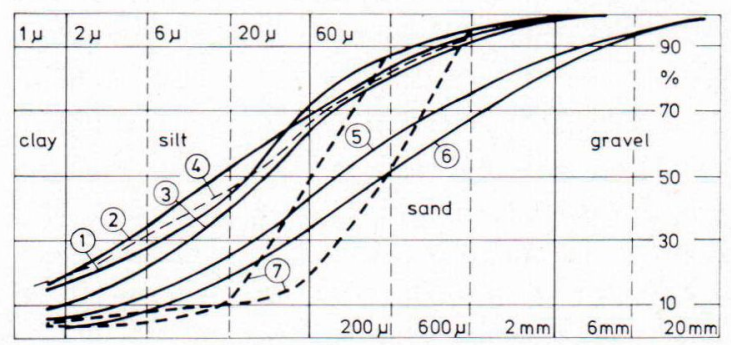

Fig. 11. Cumulative curves indicating grain size composition for basal till and common till and glaciofluvial material in the Kerkkolankangas delta. 1-3. The upper brown basal till layer, the middle dark layer and the lower brown one (cf. Fig. 8, section A). 4. Light-coloured till in association with the former (section D). 5. Till mantle covering the proximal slope of the delta (4 analyses). 6. Common sandy till in nearby areas (7 analyses). 7. Stratified sand above and below a bed of basal till ( 2 analyses). 


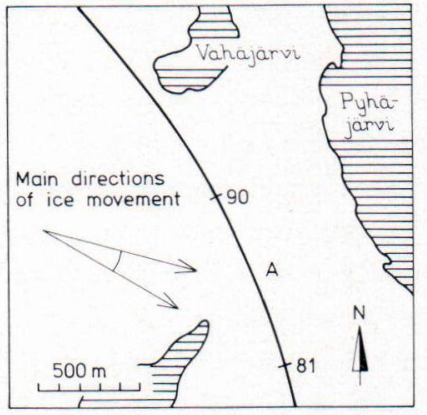

Tielinja Eura-Honkilahti, Mestilä

A
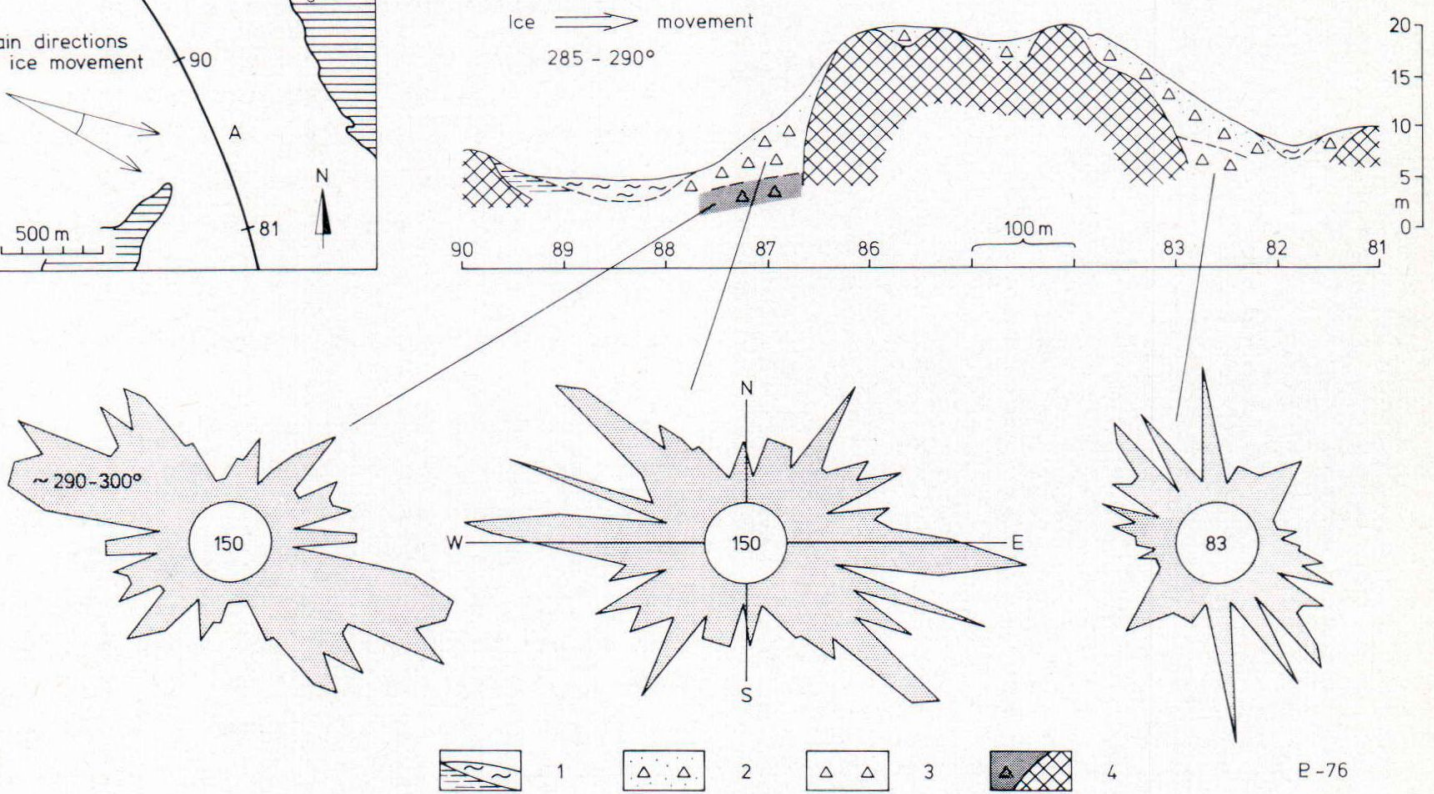

Fig. 12. The orientation of pebbles in dark basal till on the stoss side of a steep hill approximately coincides with the prevailing direction of striations of the last ice movements (map in upper left hand corner). The orientation analysis of the overlying washed sandy till did not give an equally distinct direction. On the lee side of the hill there is reddish sandy till without any clear orientation, probably because of deviations and turbulence in the movement of the ice sheet owing to local topography. Mestilä, road cutting between Eura and Honkilahti. Symbols as before.

One half of the 14 samples so far submitted to pollen analysis have exhibited abundant pollen, the other half sparse or no pollen. The proportions of arboreal pollen are: Betula 72 to 84 percent, Alnus 0 to 19 percent, Corylus and Pinus 0 to 6 and 0 to 13 percent. The highest proportions of NAP are shared alternately by Gramineae and Artemisia. The next most abundant is Cyperaceae, and finally Salix, which is only present in minor amounts. Three of the 10 samples submitted to diatom analysis exhibited a considerable diatom flora, 91-95 percent of it being large lake species, mainly Melosira islandica ssp. helvetica. The proportion of saline water forms did not exceed $0-2$ percent.

\section{Conclusions}

Nearly one hundred occurrences of dark grey basal till have been found in various parts of Finland in a rather short time, which means that deposits of this type must be fairly common in the country as a whole.

The location of basal till underlain locally by as many as two separate till layers suggests that it predates the last movements of the ice sheet. At some sites, however, the basal till is covered by glaciofluvial sand and gravel or thin littoral deposits only.

The suggestion that the dark basal till is older than common till is corroborated by the tendency of the basal till to occur on 

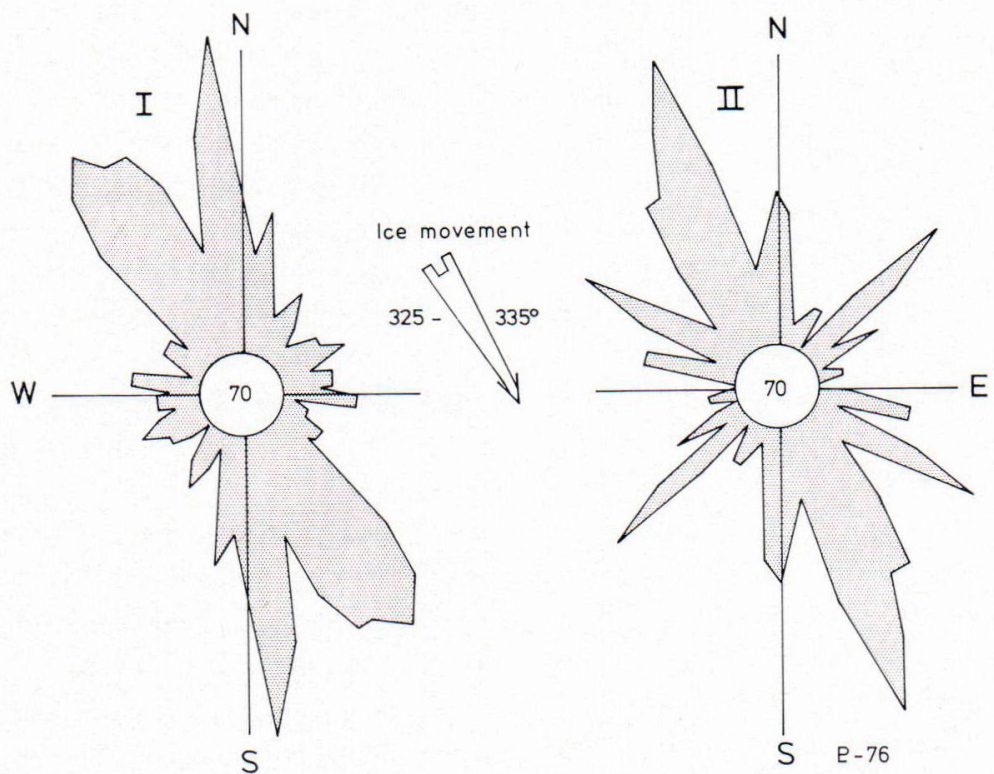

Fig. 13. Orientation diagrams from the dark grey basal till (II) and the overlying brown layer (I) coincides with the prevailing directions of striations marked between the roses. Väkkärämäki, road cutting between Pengonpohja and Kuru (cf. Fig. 3).

the lee-side of hills and in depressions in the bedrock, even through its local occurrence on the proximal side of ice-margin formations seems to contradict this assumption. It is, however, more probable that some sheets of basal till were transported from primary into secondary position by the action of the last movement of ice in the zone of icemargin formation. Kujansuu (1975) has reported dark boulder clay-like till in an analogous position in an esker in Central Lapland.
In Central and Eastern Finland the dark grey basal till is over- and underlain by reddish brown layers that occasionally differ in structure from the dark part. The common occurrence of the sequence, the welldeveloped and straight boundaries between the layers (the colour boundary often cuts through pebbles), the rare glaciodynamic and tectonic structures and the similarities in grain-size composition and in the orientation of pebbles indicate that, despite their different colour, all the layers belong to one and

Table 1. Chemical composition of the dark grey basal till and the brown layer related to it and of the common till. For details, see text.

\begin{tabular}{|l|c|c|c|c|c|c|c|c|c|c|c|c|c|}
\hline & $\begin{array}{c}\text { Number } \\
\text { of deter- } \\
\text { minations }\end{array}$ & Si \% & Al \% & Fe \% & Mg \% & Ca \% & Na \% & K \% & $\begin{array}{c}\text { Ti } \\
\text { ppm }\end{array}$ & $\begin{array}{c}\mathrm{V} \\
\text { ppm }\end{array}$ & $\begin{array}{c}\text { Cr } \\
\text { ppm }\end{array}$ & $\begin{array}{c}\text { Mo } \\
\text { ppm }\end{array}$ & $\begin{array}{c}\text { Zn } \\
\text { ppm }\end{array}$ \\
\hline Brown basal till & 5 & 61.7 & 13.2 & 9.5 & 1.8 & 5.0 & 2.8 & 3.8 & 3980 & 140 & 100 & 660 & 105 \\
Dark basal till & 11 & 68.6 & 13.1 & 7.7 & 2.4 & 5.4 & 3.7 & 4.8 & 3710 & 160 & 110 & 540 & 130 \\
Common till & 8 & 66.8 & 15.7 & 7.3 & 1.7 & 4.5 & 2.9 & 3.5 & 4390 & 140 & 90 & 540 & 90 \\
\hline
\end{tabular}


Table 2. Abundances of ferrous and ferric iron as well as manganese in dark grey basal till and the brown layer related to it. More detailed in text.

\begin{tabular}{|c|c|c|c|c|}
\hline & 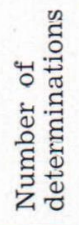 & $\begin{array}{l}\stackrel{0}{\circ} \\
+ \\
+ \\
+ \\
0 \\
\text { tr }\end{array}$ & $\begin{array}{l}\stackrel{0}{0} \\
+ \\
+ \\
+ \\
0 \\
+\end{array}$ & $\begin{array}{l}\stackrel{0}{\circ} \\
\stackrel{\mathcal{L}}{2}\end{array}$ \\
\hline Brown basal till & 7 & 1.0 & 2.0 & 0.05 \\
\hline Dark grey basal till & 8 & 1.6 & 1.4 & 0.04 \\
\hline
\end{tabular}

the same unit. The increase in ferric iron in the brown layers at the expense of ferrous iron (Table 2) suggests that the brown layers are a result of oxidation. The almost total lack of oxidised layers in southern and western Finland is surprising because in coastal areas the dark basal till occurs on relatively high hills of bedrock covered by no more than a thin porous layer of soil. Thus, conditions would have favoured oxidation even though the area emerged from Baltic Sea several thousand years later than did the occurrences in Central and Eastern Finland. No colour change towards brown as a result of oxidation has been observed in opened drying cuttings, and samples stored for 30 years show no apparent signs of oxidation.

If the concept of oxidation is correct, it took place, depending on the date of deposition of the basal till, during either an interstadial or an interglacial stage. However, both the lower and upper parts of the brown layers in the basal till beds in the ice-marginal formations have oxidised evenly, which suggests that the oxidation took place during the postglacial period. Nevertheless, even where favourable conditions prevailed, the process did not go deeper than 10 to $30 \mathrm{~cm}$,

* Determinations are based on humic matter burned from 20 to $30 \mathrm{~kg}$ of boulder clay (cf. Heikkinen 1975). whereas under conditions less favourable for oxidation layers oxidised for several metres may be encountered in the lower part of basal till beds or under younger common tills. The position of the ground water table and hence the variations in the oxidising and reducing conditions in a vertical direction do not seem to have an essential effect on colour.

The density of the dark basal till indicates that after deposition the till was submitted to a heavy load. In this respect it differs strikingly from common till. The dark basal till seems to have been rolled into a compact state while under a massive ice-sheet, and it presumably dates beginning of the last glacial advance.

The abundance of clay and silt fractions and the dark grey colour might indicate that interstadial or interglacial lacustrine sediments are essential constituents of basal till. We think that some of these sediments were caught up by the glacier as it advanced into the area during the first stage of the last glaciation, that is, at the beginning of Weichselian II (for glaciations of the late Pleistocene consult e.g. Lundquist 1974). Later the ice sheet obtained most of its material from the bedrock as a consequence of exaration. This led to the deposition of the common sandy till during the last stage of glaciation. The key role played by fine-grained sediments in the composition of dark basal till is further emphasized in some occurrences by the almost total absence of pebbles, by the presence of nebulous relics of stratified or varved structures, or by the occurrences of proper clay as bent intercalations (Sörnäinen, Helsinki). The dark colour of the basal till may also be due to the ferrous sulphide precipitated as a result of the reduction of ferrous iron and sulphates caused by the organic material. That would explain the colour of the sandy basal till too.

The fairly high humus contents show that the primary matter contained organic sub- 
stances. This is compatible with the hypothesis that lacustrine sediments are essential primary constituents of the basal till. Most of the pollen grains are smoothed and broken, which is not surprising considering that they were transported by the ice-sheet. According to Lundquist (1973), who has studied dark grey basal till in a similar stratigraphic position in Sweden, it dates at the Weichselian I stadial period. Hence, the organic substances and the clay and silt fraction would derive at least partly from the Eemian interglacial stage preceding the prime glaciation.

In the light of studies performed in Sweden (op.cit.), the orientation of pebbles in the dark basal till in the Stockholm area coincides with the approximate western direction of the Weichselian I ice-sheet. Our observations in Finland show that the orientation of dark basal till generally coincides with the directions of the final ice movements, that from the NW and NNW. In some occurrences the basal till lies on a polished rock surface in which the facets of glacial erosion and the striations continue unchanged in form and direction beneath the common till. Only in a few of the occurrences can directions be observed under the basal till that clearly deviate from the youngest ones. If the dark basal till is in its primary position and if it derives from the W I stadial, we may infer that exaration was very slight during the whole period of Weichselian glaciation. Further, it should contain pollen typical of the Eemian stage. This is not so, however, and some of the samples with relative abundant pollen contain predominantly subarctic pol-

Acknowledgements - The chemical determinations were made in the Chemistry and Geochemistry Departments of the Geological Survey; the grain-size and humus analyses were made by the Misses Annikki and Kyllikki Parkkonen. The authors were assisted in the field by Mr. Erkki Herola, Mr Timo Ruohomäki and Mr Markku Putki- len, for example 70 to 80 percent Betula. According to Korpela (1969), the pollen in the Peräpohjola interstadial deposits in South and Central Lapland is 70 to 80 percent Betula, the remainder being Pinus and Picea like in the basal till investigated. This seems to indicate that the pollen flora of the basal till has characteristics of the Peräpohjola-Jämtland interstadial. On the other hand, a Betula-dominated pollen flora of this type may have prevailed in the vicinity of the ice-sheet by the end of the Eemian interglacial too.

Bearing these facts in mind, we conclude that the dark basal till probably dates back to the initial phase of the last glaciation. If there were no interstadial in Finland between W II and W III, the basal till would date to the initial phase of W II. During that time the basal till would have been intermixed with lacustrine predominantly lacustrine sediments indicated by diatom species of large lake forms and organic substances deposited during the Peräpohjola-Jämtland interstadial. This is also compatible with the dates obtained from the basal till, that is, ages exceeding 37,000 and 45,000 years.

Since this type of dark grey basal till appears to be fairly common in Finland and presumably most of Fennoscandia, and because it is readily recognisable, it constitutes an excellent stratigraphic unit. Once its age has been established its interest will be even more enhanced. We are, however, still without proof that the dark basal till was in fact formed during one stadial only.

nen. The manuscript was translated by Mrs Gillian Häkli. The illustrations were drawn by Miss Päivi Määttänen, Miss Leena Kaijasilta and Miss Marja Verhilä. To these and all the other persons who contributed to this work the authors wish to express their most sincere thanks. 


\section{LITERATURE}

Armand, A. D., Armand, N. N., Grave, M. K., Evzerov, V. and Lebedeva, R. M. (1969) Generalized scheme of Quaternary (Anthropogen) deposits of the Kola peninsula in the light of the new data (in Russian). Main Problems of the Geomorphology and Anthropogen Stratigraphy of the Kola Peninsula. Akad. Nauk USSR. Pp. 7-24. Leningrad. VIII Congr. INQUA (France 1969).

Heikkinen, A. (1975) Radiohilimenetelmän käytöstä moreenin sisältämän vanhan hiliaineksen ajoituksessa. English summary: Radiocarbon dating of old charcoal contained in till. Geologi 27 (4): 51-53.

Kujansuu, R. and Ber, A. (1974) The till profile of Rovaniemi, Finland. Geogr. (Poznán) 10: $193-201$.

Kujansuu, R. (1975) Marrasjärven interstadiaalinen harju Keski-Lapissa. English summary: Interstadial esker at Marrasjärvi, Finnish Lapland. Geologi 27 (4): 45-50.

Låg, J. (1948) Undersøsekser over opphavsmaterialet for Østlandets morenedekker. Medd. Norske
Skogforsøksvesen 10, H. 1 (35): 223 p.

Lundquist, G. (1963) Beskrivning till jordartskarta över Gävleborgslän. English summary: Description to map of the Quaternary deposits of Gävleborgs län, Gentral Sweden. Sveriges Geol. Unders. Ser. Ca. 42. $1: 200000.181$ p.

Lundquist, J. (1958) Beskrivning till jordsartskarta över Värmlands län. Sweriges Geol. Unders. Ser. Ca. 38. $1: 200000.228$ p.

- (1973) Dark bluish boulder-clay: A possible deposit from the first Würm Glaciation. Bull. Geol. Inst. Univ. Uppsala. 5: 19-20.

- (1974) Outlines of the Weichsel glacial in Sweden. Geol. Fören. Stockholm Förhandl. 96. Pt. 4 (559): 327-339.

Virkkala, K. (1959) Maaperäkartan selitys. 2043 Kerava. Suomen Geologinen Kartta, 1: 100000. $99 \mathrm{p}$.

- (1969) Suomen moreenien rakeisuusluokitus. English summary: Classification of Finnish tills according to grain size. Terra 81 (3): 273-278.

Manuscript revied, March 10, 1976. 